\title{
COACHING DAN MENTORING PEMBUATAN VIDEO PEMBELAJARAN MENGGUNAKAN APLIKASI ANDROID DI RUMAH TAHFIZ AR-RIFAI DESA PADANG TUALANG, KEC.PADANG TUALANG, KABUPATEN LANGKAT, SUMATERA UTARA
}

\author{
Wiene Surya Putra ${ }^{1}$, Karina Wanda ${ }^{2}$ \\ ${ }^{1,2)}$ Program Studi PAI STAI Syekh H. Abdul Halim Hasan Al-Islahiyah Binjai, Sumatera Utara, FKIP, \\ Universitas STAI Al-Ishlahiyah Binjai Sumatera Utara \\ e-mail: wienesuryaputra@gmail.com, karinawanda@umsu.ac.id
}

\begin{abstract}
Abstrak
Pengabdian kepada masyarakat yang dilaksanakan adalah "Coaching dan Mentoring Pembuatan Video Pembelajaran Menggunakan Aplikasi Android di Rumah Tahfiz Ar-Rifai Desa Padang Tualang, Kec.Padang Tualang, Kabupaten Langkat, Sumatera Utara. Rumah Tahfiz adalah salah satu Lembaga Pendidikan seperti sekolah konvensional biasa yang konten pendidikannya berisi tentang mempejari Al-Quran.Kegiatan ini dilaksanakan dalam rangka menyambut semakin berkembangnya model-model pembelajaran yang dapat diterapkan dalam mengajar seharihari.Selain itu guru rumah tahfiz al-Quran juga dituntut dapat beradaptasi dengan kondisi dan situasi pandemic covid-19 dalam menerapkan model pembelajaran yang bervariasi.Kegiatan dalam Coaching ini adalah guru rumah tahfiz al-Quran-guru rumah tahfiz al-Quran dari kedua Rumah Tahfiz Ar-Rifai Desa Padang Tualang, Kec.Padang Tualang, Kabupaten Langkat, Sumatera Utara yang akan diberikan Coaching dan Mentoring dalam Pembuatan Video Pembelajaran Video Pembelajaran Menggunakan Aplikasi Android mulai dari mendowload aplikasi di android kemudian menyiapkan model pembelajaran yang digunakan, konten pembelajaran, pengambilan data yang digunakan untuk pembelajaran kelas daring dan juga bahan ajar apa yang akan digunakan dalam membuat Video Pembelajaran video pembelajaran. Guru rumah tahfiz al-Quran juga akan diberikan Video Tutorial Youtube pembuatan Video Pembelajaran video pembelajaran yang berisikan model- model pembelajaran yang dapat digunakan dan diterapkan menggunakan Video Pembelajaran video pembelajaran dalam mengajar daring.
\end{abstract}

Kata Kunci : Coaching, Video Pembelajaran, Guru rumah tahfiz al-Quran Rumah Tahfiz n AlQuran Dasar

\begin{abstract}
The title of the Community Partnership Program activity is "Coaching and Mentoring in Making Learning Video Video Pembelajaran Using Android Applications in Elementary Schools. This activity is carried out in order to welcome the growing development of learning models that can be applied in daily teaching. In addition, teachers are also required to be able to adapt to the conditions and situations of the COVID-19 pandemic in applying varied learning models. Activities in this training are teachers- teachers from both schools, namely Tahfiz Al-Quran Home Ar-Rifai who will be given Coaching and Mentoring in Making Learning Video Video Pembelajaran Using Android Applications starting from downloading applications on android then preparing the learning model used, learning content, data collection used for learning online classes and also what teaching materials will be used in making learning video Video Pembelajaran. Teachers will also be given a guidebook for making learning video Video Pembelajaran that contains learning models that can be used and applied using instructional video Video Pembelajaran in online teaching.
\end{abstract}

Keywords: Coaching, Mentoring Training, Video Pembelajaran, Al-Quran School 


\section{PENDAHULUAN}

Undang-Undang Guru dan Dosen Nomor 14 Tahun guru professional dituntut memenuhi empat kompetensi pokok, yakni: 1) pedagogi, 2) professional, 3) sosial, dan 4) pribadi. Dari empat kompetensi ini, dapat diidentifikasi beberapa kompetensi utama yang wajib dimiliki guru, yakni adalah: (1) mengembangkan kurikulum yang terkait dengan bidang pembelajaran yang diampu, (2) menyelenggarakan kegiatan pembelajaran yang mendidik, (3) mengembangkan materi pembelajaran yang diampu secara kreatif dan (4) memanfaatkan teknologi informasi dan komunikasi untuk berkomunikasi dan mengembangkan diri. UU ini, disusul dengan Peraturan Pemerintah Nomor 19 tahun 2006 tentang standarisasi pendidikan.

Melalui UU dan Peraturan di atas, guru termasuk guru rumah tahfiz al-Quran tidak hanya mengajar. Guru rumah tahfiz al-Quran dituntut melakukan langkah-langkah strategis untuk meningkatkan kualitas dirinya dan secara otomatis kualitas pembelajarannya. Fungsi dan peran guru rumah tahfiz al-Quran, dengan demikian, juga menjadi berubah. Dengan nalar di atas, langkah-langkah yang harus dilakukan guru rumah tahfiz al-Quran adalah sebagai berikut: 1). Melaksanakan pengembangan diri melalui kegiatan diklat fungsional dan kegiatan kolektif guru rumah tahfiz al-Quran; 2). Pelaksanaan karya inovatif penemuan penelitian tepat guna, penemuan/penciptaan atau pengembangan karya seni, 3.) pembuatan/pemodifikasian alat peraga, penyusunan standar dan pedoman.

Pengakuan atas profesi guru rumah tahfiz al-Quran memiliki konsekuensi logis yang penting bagi guru rumah tahfiz al-Quran. Salah satu konsekuensi logis itu adalah bahwa guru rumah tahfiz al-Quran dituntut untuk selalu memperbarui atau mengembangkan dirinya. Secara lebih luas, guru rumah tahfiz alQuran dituntut untuk selalu mengembangkan keprofesiannya secara terus menerus, misalnya melalui pendidikan dan Coaching, pengembangan bahan ajar dan alat peraga, dan sebagainya. Kegiatan pengembangan bahan ajar dan alat peraga umumnya merupakan suatu hal yang tidak mudah untuk dilakukan oleh guru rumah tahfiz al-Quran. Ironisnya lagi, terkadang pengembangan bahan ajar dan alat peraga terkhusus Video Pembelajaran pembelajaran berbasis video ini digunakan ketika hanya ada stakeholder yang menyediakannya. Pada sisi lain tuntutan dan tantangan yang dihadapi guru rumah tahfiz al-Quran dalam melaksanakan tugas profesinya makin beragam dan berat apalagi disaat pandemic covid saat ini proses belajar mengajar dilaksanakan secara daring. Seperti layaknya seorang dokter, bahkan dokter spesialis, guru rumah tahfiz al-Quran pun dituntut untuk mampu memecahkan berbagai permasalahan yang dihadapinya dalam kaitan dengan pengelolaan pendidikan dan pembelajaran di Rumah Tahfiz al-Quran. Sementara itu, kondisi pandemic covid-19 dan perkembangan ilmu pengetahuan dan teknologi (iptek) demikian pesatnya dewasa ini. Guru rumah tahfiz al-Quran ditantang untuk selalu dapat mengikuti perkembangan iptek itu jika tidak ingin 'tergilas oleh waktu' dan sistem belajar mengajar saat pademi covid-19. Tuntutan atau tantangan profesi dan perubahan kondisi saat ini harus dapat dijawab guru rumah tahfiz al-Quran melalui tindakan nyata yang berawal dari pribadi guru rumah tahfiz al-Quran itu sendiri. Oleh karena itu, pengembangan keprofesian guru rumah tahfiz al-Quran menjadi sebuah keniscayaan.

Salah satu upaya yang cukup menjanjikan bagi pengembangan materi pembelajaran guru rumah tahfiz al-Quran itu adalah melakukan kegiatan mengembangkan materi pembelajaran yang diampu secara kreatif dan (4) memanfaatkan teknologi informasi dan komunikasi untuk berkomunikasi dan mengembangkan diri. melalui Video Pembelajaran pembelajaran berbasis video ini, guru rumah tahfiz alQuran dapat melakukan sekaligus minimal tiga hal, yaitu mampu beradaptasi, mempunyai skills, dan mengembangkan keprofesian secara berkelanjutan. muslich (2009) mengatakan bahwa Video Pembelajaran pembelajaran berbasis video menawarkan peluang strategi pengembangan kinerja melalui pemecahan masalah-masalah pembelajaran (teaching-learning probleems solving), sebab pendekatan dalam Video Pembelajaran pembelajaran berbasis video menempatkan guru rumah tahfiz al-Quran sebagai pendidik sekaligus sebagai agen perubahan. melakukan Video Pembelajaran pembelajaran berbasis video bahkan sangat disarankan beberapa pakar karena nilai manfaat dari kegiatan Video Pembelajaran pembelajaran berbasis video itu sangat besar, baik bagi guru rumah tahfiz al-Quran sendiri maupun bagi pendidikan dan pembelajaran, siswa, dan Rumah Tahfiz al-Quran. wiriaatmadja (2008) mengatakan bahwa jawaban paling utama terhadap pertanyaan mengapa guru rumah tahfiz al-Quran harus melakukan Video Pembelajaran pembelajaran berbasis video ialah untuk mengubah citra dan meningkatkan keterampilan profesional guru rumah tahfiz al-Quran. dengan kata lain, dapat dikatakan bahwa Video Pembelajaran pembelajaran berbasis video merupakan sebuah pilihan solutif bagi guru rumah tahfiz alQuran untuk membantu memecahkan berbagai persoalan pembelajaran dan/atau pendidikan yang 
dikelolanya di samping untuk membantu mengembangkan keprofesian guru rumah tahfiz al-Quran secara berkelanjutan.

Peraturan menteri pendidikan nasional nomor 16 tahun 2007 tentang standar kualifikasi akademik dan kompetensi guru rumah tahfiz al-Quran a.l. mengatur tentang kompetensi guru rumah tahfiz al-Quran. pada kompetensi pedagogik terdapat kompetensi inti guru rumah tahfiz al-Quran. salah satu kompetensi inti guru rumah tahfiz al-Quran itu adalah melakukan tindakan reflektif untuk peningkatan kualitas pembelajaran. kompetensi inti guru rumah tahfiz al-Quran ini dijabarkan menjadi kompetensi guru rumah tahfiz al-Quran, salah satunya adalah mampu membuat Video Pembelajaran pembelajaran kompetibel dengan situasi saat ini untuk meningkatkan kualitas pembelajaran. hal ini berarti bahwa melakukan Video Pembelajaran pembelajaran berbasis video merupakan bagian penting tuntutan standar kompetensi yang harus dicapai guru rumah tahfiz al-Quran.

Hopkins (dalam Kunandar, 2008) memberikan batasan tentang Video Pembelajaran pembelajaran berbasis video sebagai "suatu bentuk penyelidikan refleksi diri yang dilakukan oleh peserta dalam situasi sosial (termasuk pendidikan) untuk meningkatkan rasionalitas dan keadilan: (a) praktik sosial atau pendidikan mereka sendiri; (b) pemahaman mereka tentang praktik-praktik ini; dan (c) situasi di mana praktik dilakukan." dalam konteks pendidikan, hal di atas mengandung pengertian bahwa Video Pembelajaran pembelajaran berbasis video merupakan suatu bentuk refleksi diri yang dilakukan pendidik untuk mengembangkan rasionalitas terhadap pelaksanaan praktik pendidikan atau pembelajaran dan memperdalam pemahaman terhadap kondisi pelaksanaan praktik pendidikan atau pembelajaran.

Kemmis dan Mc.taggart (dalam Muslich, 2009) mengemukakan bahwa Video Pembelajaran pembelajaran berbasis video merupakan studi untuk memperbaiki diri sendiri atau pengalaman kerja sendiri yang dilaksanakan secara sistematis, terencana, dan mawas diri. berdasarkan pandanganpandangan di atas, dapat dikatakan bahwa Video Pembelajaran pembelajaran berbasis video merupakan suatu bentuk penelitian praktis yang dilakukan pendidik untuk merefleksikan tindakan yang dilaksanakan dalam rangka memperbaiki praktik pembelajaran atau pendidikan.

Terdapat beberapa prinsip yang perlu diperhatikan oleh guru rumah tahfiz al-Quran dalam pelaksanaan Video Pembelajaran pembelajaran berbasis video. pada modul membimbing guru rumah tahfiz al-Quran dalam penelitian tindakan kelas (materi Coaching penguatan kemampuan pengawas sekolah tahun 2010), yang dikeluarkan oleh direktorat tenaga kependidikan, beberapa prinsip Video Pembelajaran pembelajaran berbasis video adalah sebagai berikut. pertama, tindakan dan pengamatan dalam proses penelitian yang dilakukan tidak boleh mengganggu atau menghambat kegiatan utama, misalnya bagi guru rumah tahfiz al-Quran tidak boleh sampai mengorbankan kegiatan pembelajaran. kedua, masalah penelitian yang dikaji merupakan masalah yang cukup merisaukan dan berpijak dari tanggung jawab profesional guru rumah tahfiz al-Quran. ketiga, metode pengumpulan data yang digunakan tidak menuntut waktu yang lama sehingga berpeluang menggangu proses pembelajaran. keempat, metodologi yang digunakan harus terencana secara cermat sehingga tindakan dapat dirumuskan dalam suatu hipotesis tindakan yang dapat diuji di lapangan. kelima, permasalahan atau topik yang dipilih harus benar-benar nyata, menarik, mampu ditangani, dan berada dalam jangkauan kewenangan peneliti untuk melakukan perubahan. keenam, peneliti harus tetap memperhatikan etika dan tata krama penelitian serta rambu-rambu pelaksanaan yang berlaku umum. ketujuh, kegiatan Video Pembelajaran pembelajaran berbasis video pada dasarnya merupakan kegiatan yang berkelanjutan karena tuntutan terhadap peningkatan dan pengembangan akan menjadi tantangan sepanjang waktu. kedelapan, meskipun kelas atau mata pelajaran merupakan tanggung jawab guru rumah tahfiz al-Quran, namun tinjauan terhadap Video Pembelajaran pembelajaran berbasis video tidak terbatas dalam konteks kelas dan atau mata pelajaran tertentu melainkan dalam perspektif misi Rumah Tahfiz al-Quran. kita dapat memulai Video Pembelajaran pembelajaran berbasis video dari permasalahan yang kita temui atau hadapi dalam mengelola pembelajaran.

Dalam hal ini, guru rumah tahfiz al-Quran, akan diberi Coaching dan Mentoring pembuatan Video Pembelajaran pembelajaran berbasis video dengan menggunakan Video Tutorial Youtube model - model pembelajaran. berdasarkan dasar pemikiran tentang Video Pembelajaran pembelajaran berbasis video diatas, penguatan kompetensi sdm guru rumah tahfiz al-Quran perlu mendapat perhatian civitas akademika di lingkungan STAI Al-Ishlahiyah Binjai mempunyai tanggung jawab moral ikut mengembangkan Rumah Tahfiz al-Quran yang merupakan bagian dari amal usaha STAI Al-Ishlahiyah Binjai untuk meningkatkan kualitas tenaga pendidik atau guru rumah tahfiz al-Quran setempat. 


\section{METODE}

\section{Khalayak Sasaran}

Khalayak sasaran pengabdian masyarakat ini tentu saja adalah guru rumah tahfiz al-Quran di Rumah Tahfiz Al-Quran Ar-Rifai Desa Padang Tualang . khalayak sasaran diutamakan seluruh guru rumah tahfiz al-Quran Rumah Tahfiz al-Quran tersebut yang berjumlah 15 orang. melalui kegiatan ini diharapkan khalayak sasaran dapat menerapkan IPTEK dalam bentuk membuat Video Pembelajaran pembelajaran berbasis video dengan menggunakan aplikasi android.

\section{Metode Kegiatan}

Mentoring dalam bentuk Coaching dan workshop pembuatan Video Pembelajaran pembelajaran berbasis video dengan menggunakan aplikasi android Video Pembelajaran pembelajaran berbasis video yang akan dibuat oleh guru rumah tahfiz al-Quran diupayakan dapat meningkatkan hasil belajar siswa dengan menggunakan model - model pembelajaran di kelas dan dapat meningkatkan sasaran kinerja guru rumah tahfiz al-Quran tersebut.

\section{Langkah - Langkah Kegiatan}

Pelaksanaan pengabdian kepada masyarakat ini dilakukan dengan tiga tahapan, dimana tahap pertama merupakan tahapan persiapan. pada tahap ini kelompok pengabdian masyarakat melakukan survey pendahuluan untuk melihat kondisi di lapangan mengenai sarana dan prasarana serta kompetensi guru rumah tahfiz al-Quran dalam mengajar daring. tahap selanjutnya merupakan tahapan pelaksanaan kegiatan program. dalam tahap ini tim akan melakukan kegiatan Coaching dan Mentoring pembuatan Video Pembelajaran pembelajaran berbasis video. dalam tahap pelaksanaan ini kelompok pengabdian masyarakat memberikan Coaching membuat Video Pembelajaran pembelajaran berbasis video dan juga memberikan guru rumah tahfiz al-Quran tersebut Video Tutorial Youtube model - model pembelajaran berbasis video menggunakan aplikasi android yang akan menjadi referensi guru rumah tahfiz al-Quran dalam membuat Video Pembelajaran pembelajaran berbasis video. guru rumah tahfiz al-Quran juga dipandu dari setiap masing - masing bab yang ada pada draft Video Pembelajaran pembelajaran berbasis video. tahap yang terakhir adalah tahap evaluasi. pada tahap ini dilakukan evaluasi atas hasil yang telah dicapai oleh peserta Coaching. masukan dan perbaikan lebih lanjut dapat dilakukan pada tahap ini. evaluasi diberikann dengan mengumpulkan data yang diperoleh dari kegiatan Coaching. data diambil dengan menyimpulkan pemahaman guru rumah tahfiz al-Quran ketika membuat Video Pembelajaran pembelajaran berbabasis video. indicator ketercapaian tujuan program kemitraan ini adalah bahwa $80 \%$ guru rumah tahfiz al-Quran sudah memahami dan dapat membuat Video Pembelajaran pembelajaran berbasis video dan melihat hasil proses belajar mengajar pada kelasnya masing - masing. adapun langkahlangkah kegiatan ini dapat dijelaskan sebagai berikut :

\section{Langkah 1 :}

Peserta Coaching diminta mendownload aplikasi inShot kemudian diberikan materi tentang membuat Video Pembelajaran pembelajaran berbasis video menggunakan aplikasi android.

\section{Langkah 2 :}

Peserta diberikan kesempatan untuk mendiskusikan materi yang telah diberikan. Kesempatan tanya jawab cara pembuatan dan pengeditan video diberikan untuk memperjelas hal-hal yang masih menjadi keraguan.

\section{Langkah 3 :}

peserta berlatih untuk membuat Video Pembelajaran pembelajaran berbasis video

\section{Langkah 4 :}

Peserta melakukan penelitian dengan langsung menguji coba menggunakan dikelasnya masing - masing untuk melihat peningkatan hasil belajar siswa dengan menggunakan model pembelajaran yang bervariasi.

\section{Langkah 5 :}

peserta melakukan presentasi Video Pembelajaran pembelajaran berbasis video

\section{Langkah 6 :}

Hasil karya peserta dikumpulkan dan dianalisis untuk diberikan masukan dan perbaikan lebih lanjut. 


\section{HASIL DAN PEMBAHASAN}

\section{Kegiatan Koordinasi Awal}

Pelaksanaan kegiatan pengabdian kepada masyarakat ini dilaksanakan di Rumah Tahfiz Al-Quran Ar-Rifai Desa Padang Tualang . Pada pra- kegiatan tim mengadakan perencanaan dengan mengunjungi untuk melakukan wawancara untuk kegiatan ini dengan Pemilik Rumah Tahfiz al-Quran Rumah Tahfiz Al-Quran Ar-Rifai Desa Padang Tualang.

Berdasarkan hasil wawancara danfakta-fakta dilapangan, banyak ditemukan guru rumah tahfiz alQuran masih menggunakan Video Pembelajaran pembelajaran konvensional, yaitu Video Pembelajaran pembelajaran yang tersedia dan dilakukan tanpa adanya perencanaan, menyiapkan bahan dan menyusunnya sediri. Hal ini tentunya akan berdampak pada kemampuan siswa, pembelajaran menjadi tidak menarik, bersifat monoton dan tidak sesuai dengan kebutuhan siswa.

Dengan adanya permasalah yang muncul tersebut, ada beberapa yang disepakati, antara lain yaitu, (1) Jenis Video Pembelajaran yang akan diberikan Coaching kepada para guru rumah tahfiz al-Quran, maka jenis Video Pembelajaran yang akan dilatihkan kepada guru rumah tahfiz al-Quran yaitu Video Pembelajaran berbasis Media Video Pembelajaran Menggunakan Aplikasi Android. Pemilihan Video Pembelajaran berbasis Media Video Pembelajaran Menggunakan Aplikasi Android karena Video Pembelajaran merupakan aplikasi professional dalam membuat video. Video Pembelajaran termasuk Video Pembelajaran yang digunakan oleh para guru rumah tahfiz al-Quran professional dalam era revolusi industri 4.0, (2) Jadwal pelaksanaan pengabdian; berdasarkan kesepakatan pelaksanaan pengabdian masyarakat akan dilaksanakan pada bulan Juli namun karena kondisi masih dalam suasana pandemic Covid- 19, maka kegiatan ini diundur dan dilaksanakan pada hari senin 28 Agustus 2021. Kegiatan ini dilaksanakan di Rumah Tahfiz Al-Quran Ar-Rifai Desa Padang Tualang yang diikuti oleh 5 guru rumah tahfiz al-Quran dari perwakilan setiap kelas serta melibatkan 2 mahasiswa KKN.

\section{Persiapan Coaching dan Mentoring Video Pembelajaran Berbasis Media Video Pembelajaran Menggunakan Aplikasi Android}

Kegiatan pengabdian masyarakat yang berjudul "Coaching dan Mentoring Video Pembelajaran Berbasis Media Video Pembelajaran Menggunakan Aplikasi Android bagi guru rumah tahfiz al-Quran Rumah Tahfiz Al-Quran Ar-Rifai Desa Padang Tualang" bertujuan untuk mengembangkan kompetensi guru rumah tahfiz al-Qurandalam mengajar di dalam kelas dengan menggunakan Video Pembelajaran berbasis Media Video Pembelajaran Menggunakan Aplikasi Android. Media Video Pembelajaran Menggunakan Aplikasi Android merupakan aplikasi professional dalammendesain video Pembelajaran yang dapat menciptakan pembelajaran yang kreatif dan menyenangkan.

Tim menyiapkan master Media Video Pembelajaran Menggunakan Aplikasi Android untuk dibagikan kepada guru rumah tahfiz al-Quran supaya dapat diinstal di laptopnya masing- masing dan membagikan video tutorial youtube pembuatan Video Pembelajaran berbasis Media Video Pembelajaran Menggunakan Aplikasi Android yang sebelumnya telah disusun oleh tim . Sementara itu, mitra Rumah Tahfiz Al-Quran Ar-Rifai Desa Padang Tualang menyediakan ruangan untuk kegiatan pengabdian serta peralatan seperti infokus. Ruangan yang digunakan adalah salah satu kelas yang telah dilengkapi infokus untuk menampilkan tutorial pembuatan Video Pembelajaran berbasis Media Video Pembelajaran Menggunakan Aplikasi Android.

Video tutorial youtube dalam Coaching dan Mentoring ini disusun berdasarkan kebutuhan dalam membuat Video Pembelajaran berbasis Media Video Pembelajaran Menggunakan Aplikasi Android. Tahapan dalam penyusunan video tutorial youtube ini yaitu:

Perencanaa, di dalam perencanaan iniada beberapa langkah yang dilakukan yaitu (1)Merumuskan tujuan umum dan khusus. Tujuan umum dalam pembuatan video tutorial youtube iniadalah guru rumah tahfiz al-Quran dapat mengikuti setiap langkah yang ada dapan video tutorial youtube ini dalam membuat Video Pembelajaran berbasis Media Video Pembelajaran Menggunakan Aplikasi Android, sedangkan tujuan khususnya guru rumah tahfiz al-Quran dapat berkreasi dalam membuat Video Pembelajaran yang menarik dan mendorong siswa dapat aktif dalam pembelajaran; (2) Pemetaan konsep video tutorial youtube. Pemetaan konsep Video Tutorial Youtube digunakan oleh penulis untuk memberikan gambaran/alur dari video tutorial youtube yang akan dihasilkan; (3) Menentukan bentuk Video Pembelajaran yang dihasilkan. Penting menentukan bentuk Video Pembelajaran yang akan dihasilkan berdasarkan Video Tutorial Youtube ini sebab tampilan da nisi serta aksesoris Video Pembelajaran akan mendukung pembelajaran lebih diminati oleh siswa. Persiapan, pada langkah persiapan ini video tutorial youtube akan dirancang sebagai berikut: 
(1) Menemukan ide. Menjabarkan materi- materi yang telah disusun berdasarkan pemetaan konsep dari Video Tutorial Youtube ; (2) mempertimbangkan sumber-sumber yang mendukung. Keakuratan informasi yang dibutuhkan dalam membuat video tutorial youtube ini menjadi unsur yang harus dipertimbangkan; (3) menentukan desain grafis. Desain grafis yang menarik akan membuat pembaca menjadi tertarik untuk mempelajari Video Tutorial Youtube tersebut; (4) menentukan komponen fisik video tutorial youtube. Komponen fisik dari video tutorial youtube ini terdiri dari Video Tutorial Youtube.

Perancangan, membuat rancangan awal video tutorial youtube (prorotype). Berikut ini Video Tutorial Youtube yang telah dirangcang oleh penulis:

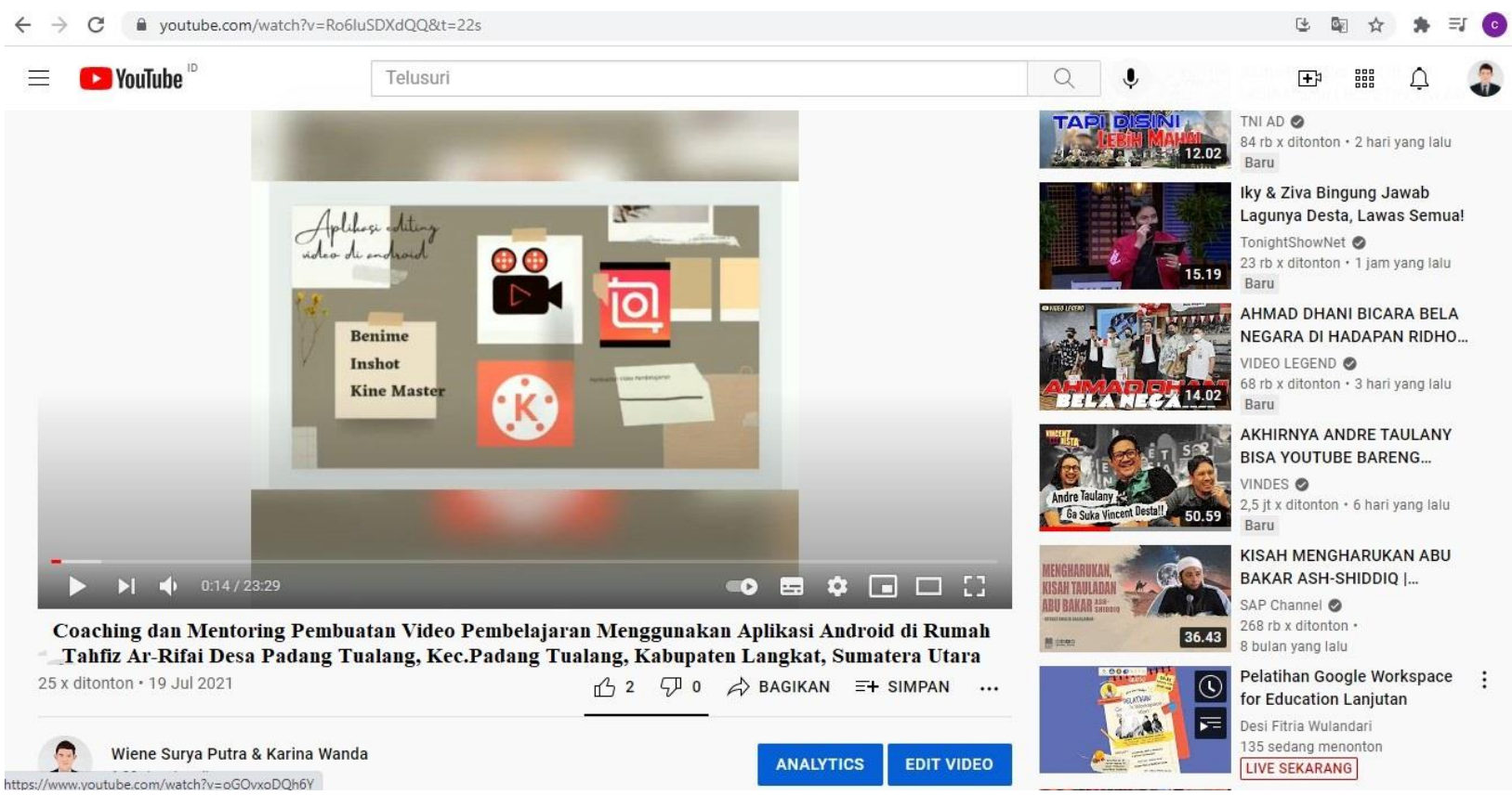

Gambar 1. Video tutorial youtube Pembuatan Video Pembelajaran Video Pembelajaran Menggunakan Aplikasi Android

Berdasarkan Video Tutorial Youtube di atas, akan dihasilkan sebuah Video Pembelajaran pembelajaran berbasis Media Video Pembelajaran Menggunakan Aplikasi Android.

\section{Pelaksanaan Pengabdian}

Pengabdian dilaksanakan kepada guru rumah tahfiz al-Quran-guru rumah tahfiz al-Quran berupa Coaching dan Mentoring pembuatan Video Pembelajaran berbasis Media Video Pembelajaran Menggunakan Aplikasi Android yang kreatif dan menyenangkan bagi siswa. Melalui kegiatan ini, akan membuka wawasan guru rumah tahfiz al-Quran bahwa banyak aplikasi yang dapat digunakan untuk membuat Video Pembelajaran danmengembangkan keterampilan guru rumah tahfiz al-Quran dalam menyajikan pembelajaran yang menarik bagi siswa dengan menggunakan Video Pembelajaran berbasis Media Video Pembelajaran Menggunakan Aplikasi Android. Selain itu, dengan adanya keterampilan tersebut, masyarakat sasaran memiliki kesempatan menciptakan proses pembelajaran yang lebih menarik dan efektif; dapat mengembangkan Video Pembelajaran pembelajaran yang kreatif dan inovatif untuk mendorong motivasi, perkembangan kognisi, perkembangan interpersonal dan perkembangan aspek sosial yang dimiliki. Rahmawati et al. (2017) menyatakan bahwa penggunaan teknologi dalam pembelajaran dapat meliputi berbagai hal yang berkaitan dengan proses, alat bantu, manipulasi dan pengelolaan informasi.

Keberhasilan kegiatan ini dapat diukur dan dilihat dengan mengamati kinerja para guru rumah tahfiz al-Quran yang mempu membuat sendiri Video Pembelajaran berbasis Media Video Pembelajaran Menggunakan Aplikasi Android. Selain itu juga, dengan adanya indikator pencapaian yang telah ditetapkan bahwa pengabdian ini dinyatakan berhasil apabila guru rumah tahfiz al-Quran sudah memiliki minimal 1 Video Pembelajaran berbasisMedia Video Pembelajaran Menggunakan Aplikasi Android untuk dapat digunakan di dalam kelas. Pengembangan Video Pembelajaran berbasis Media 
Video Pembelajaran Menggunakan Aplikasi Android yang sukses dibuatoleh para guru rumah tahfiz alQuran dapat diimplementasikan pada tema-tema yang berbeda yang terdapat di dalam kurikulum 2013. Selain itu juga dapat meningkatkan life skill guru rumah tahfiz al-Quran (Nugraheny et al., 2018)

Berdasarkan hasil pelaksanaan ini terdapat 10 guru rumah tahfiz al-Quran yang mampu membuat Video Pembelajaran pembelajaran berbasis Media Video Pembelajaran Menggunakan Aplikasi Android atau 83,33\% guru rumah tahfiz al-Quran yang mampu membuat Video Pembelajaran pembelajaran berbasis Video Pembelajaran.

Android dengan berbagai revisi. Dan terdapat 2 orang guru rumah tahfiz al-Quran atau 16,66\% belum mampu membuat Video Pembelajaran pembelajaran menggunakan Media Video Pembelajaran Menggunakan Aplikasi Android. Hal ini terjadi karena guru rumah tahfiz al-Quran masih kesulitan menggunakan teknologi dan masih pertama sekali menggunakan Media Video Pembelajaran Menggunakan Aplikasi Android sebagai aplikasi pembuatVideo Pembelajaran pembelajaran.

Media Video Pembelajaran Menggunakan Aplikasi Android ini berhasil membuka wawasan guru rumah tahfiz al-Quran dan mengembangkan kemampuan guru rumah tahfiz al-Quran dalam membuat Video Pembelajaran pembelajaran di Rumah Tahfiz Al-Quran Ar-Rifai Desa Padang Tualang. Para guru rumah tahfiz al-Quran telah mampumengembangkan Video Pembelajaran dengan menggunakan Media Video Pembelajaran Menggunakan Aplikasi Android denga berbagai tema yang terdapat dalam kurikulum 2013. Untuk itu kegiatan ini dapat memberikan manfaat dalam meningkatkan mengembangkan kemampuan guru rumah tahfiz al-Quran, kreativitasdan kesadaran pentingnya Video Pembelajaran dalam pembelajaran.

Berikut tim pengabdian memberikan Coaching dan Mentoring kepada mitra dalam pembuatan Video Pembelajaran pembelajaranberbasis Media Video Pembelajaran Menggunakan Aplikasi Android

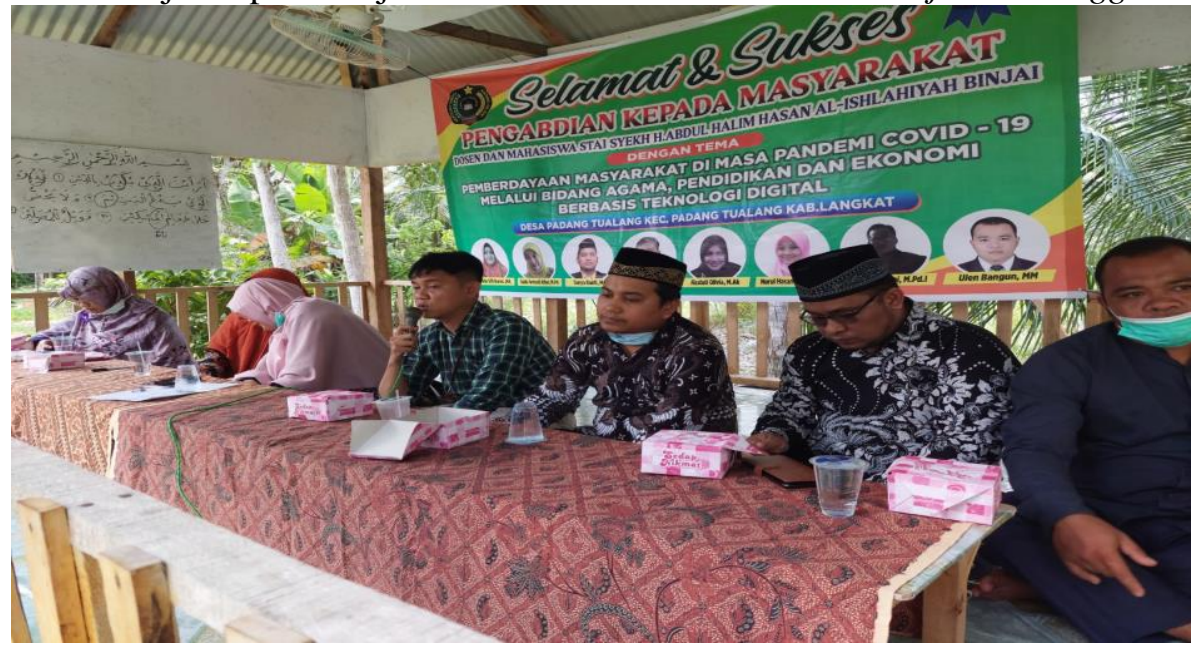

Gambar 2. Mentoring Guru rumah tahfiz al-Quran Membuat Video Pembelajaran Pembelajaran Berbasis Media Video Pembelajaran Menggunakan Aplikasi Android

\section{SIMPULAN}

Untuk keberlanjutan kegiatan ini perlu juga perhatian dari segala pihak terutama Bapak Pemilik Rumah Tahfiz al-Quran selaku supervisor Rumah Tahfiz al-Quran untuk mengontrol dan mengawasi guru rumah tahfiz al-Quran dalam menggunakan Video Pembelajaran berbasis Media Video Pembelajaran Menggunakan Aplikasi Android dan dikarenakan keterbatasan waktu juga tidak banyak materi yang tersampaikan ditambah lagi guru rumah tahfiz al-Quran barupertama kalinya menggunakan Media Video Pembelajaran Menggunakan Aplikasi Android sebagai Video Pembelajaran .Program kepada masyarakat () melalui Coaching dan Mentoring pembuatan Video Pembelajaran berbasis Android.

\section{SARAN}

Dalam pelaksanaan pengabdian ini, ada beberapa kendala yang dihadapi oleh tim diantaranya HP yang dimiliki oleh guru rumah tahfiz al-Quranterkadang kurang canggih saat penginstalan software Media Video Pembelajaran Menggunakan Aplikasi Android, guru rumah tahfiz al-Quran belum memiliki kemampuan digital yang baik sehingga perlu dilatih. 


\section{DAFTAR PUSTAKA}

Nurgayah. (2011). Strategi Dan Metode Pembelajaran. Cita Pustaka.

Rahmaibu, F. H., Ahmadi, F., \& Prasetyaningsih, F. D. (2017). Pengembangan Video Pembelajaran Pembelajaran

Ali, M. (2018). Media Video Pembelajaran Menggunakan Aplikasi Android Untuk Inovasi Pengajaran Matematika Dan SainsSDN Kota Baubau. Jurnal PengabdianKepada Masyarakat MEMBANGUN NEGERI, 2(2), 85-93.

Angraini, L. M., Sudiarta, I. W., Qomariyah, N., Alaa, S., \& Handayana, I. G. N. Y. (2019). Peningkatan Kompetensi Komputasi Fisika Dan Kimia Untuk Mahasiswa Program Studi Fisika FMIPA Universitas Mataram. SELAPARANG. Jurnal Pengabdian Masyarakat Berkemajuan, 2(3), 37-41.

Kartimi, Mulyani, A., \& Riyanto, O. R. (2019). Pemberdayaan Guru rumah tahfiz al-Quran Dalam Implementasi Pembelajaran Abad 21. DIMASEJATI, 1(2), 160-170.

Mulyono, A. (2009). Pendidikan Bagi Anak Kesulitan Belajar. Rineka Cipta.

Nugraheny, D., Wintolo, H., Kusum, A., \& Sudaryanto. (2018). Mentoring Pembuatan Bahan Ajar Berbasis MultiVideo Pembelajaran Menggunakan Media Video Pembelajaran Menggunakan Aplikasi Android Bagi Para Guru rumah tahfiz al-Quran SD IT Salsabila Al Muthi ' in, Yogyakarta. Jurnal Pengabdian Mayarakat BidangTeknologi, KACANEGARA, 1(1), 23-28.

Menggunakan Adobe Android Untuk Meningkatkan Hasil Belajar PKn. Jurnal Kreatif : Jurnal Kependidikan Dasar, 7(1).

Rahmawati, F., Haryanto, \& Alamsyah. (2017).Coaching Model Pembelajaran Berbasis Teknologi Informasi Dan Komunikasi Bagi Guru rumah tahfiz al-Quran SMP Negeri 2 Jati Agung Lampung Selatan. Adiguna: JurnalPengabdianDan Pemberdayaan Masyarakat, 2(2), 20-24. http://jurnal.stkippgribl.ac.id/index.php/adiguna

Sani, A. R. (2014). Pembelajaran Saintifik Untuk Implementasi Kurikulum 2013 (Y. S. Hartati (ed.)). Bumi Aksara.

Sari, H. L., \& Negara, E. K. (2011). Video Pembelajaran Pembelajaran Kimia Terpadu Pada Madrasah Tsanawiyah Negeri (MAN) 2Kota Bengkulu. Jurnal Video Pembelajaran Infotama, 7(2), 103-120.

Surachman, E. (2013). WorkshopPemanfaatan Video Pembelajaran Pembelajaran Sebagai Upaya Peningkatkan Efektifitas Pembelajaran Serta Profesionalitas Pendidik Di SMP Negeri 194 Jakarta. Jurnal Sarwahita, 13(2), 111-119. https://doi.org/DOI : https://doi.org/10.21009/sarwahita.132.06

Tri, S., \& Atika, N. H. (2018). Penggunaan danPemanfaatan Teknologi Informasi dan Komunikasi (P2TIK) Sektor Pendidikan2018.

Umbara, U., Rosyid, A., \& Setiawan, D. L.(2019). Coaching Pembuatan Video Pembelajaran Pembelajaran Matematika BerbasisAndroid Menggunakan Adobe Animatebagi Guru rumah tahfiz al-Quran SMP diKabupaten Kuningan. Jurnal Pengabdian Pada Mayarakat,4(1),93-104.https://doi.org/10.30653/002.201941.8 4 